\title{
Cedecea davisae gen. nov., sp. nov. and Cedecea lapagei sp. nov., New Enterobacteriaceae from Clinical Specimens
}

\author{
PATRICK A. D. GRIMONT, ${ }^{1}$ FRANCINE GRIMONT, ${ }^{1}$ J. J. FARMER III, ${ }^{2}$ aND MARY A. ASBURY ${ }^{2}$ \\ Service des Entérobactéries, INSERM Unit 199, Institut Pasteur, F-75724 Paris Cedex 15, France, ${ }^{1}$ and \\ Enteric Section, Centers for Disease Control, Atlanta, Georgia $30333^{2}$
}

\begin{abstract}
We propose the name Cedecea gen. nov. for a group of organisms in the Enterobacteriaceae that were isolated from clinical sources in North America (the clinical significance of these organisms is unknown). This name was coined by two of us (P.A.D.G. and F.G.) from the letters CDC, the abbreviation for the Centers for Disease Control, where the organisms were originally discovered. Phenotypically, Cedecea resembles no other group of Enterobacteriaceae; the members of this genus are lipase positive, resistant to colistin and cephalothin, and negative for deoxyribonuclease, gelatin liquefaction, and utilization of $\mathrm{L}$ arabinose and L-rhamnose. Deoxyribonucleic acid relatedness studies showed that Cedecea strains were 32 to $100 \%$ related to each other and less than $23 \%$ related to other members of the Enterobacteriaceae. We found five deoxyribonucleic acid hybridization groups among 17 Cedecea strains, but three of these groups contained only 1 strain (strains 001,002 , and 012 ). Two deoxyribonucleic acid hybridization groups were named. Cedecea davisae sp. nov. (nine strains), the type species of the genus, fermented sucrose and D-xylose and was positive in the ornithine decarboxylase and ascorbate tests. $C$. davisae grew in a mineral salts medium with glucose as the carbon source only if the medium was supplemented with $0.1 \mu \mathrm{g}$ of thiamine per ml. The type strain of $C$. davisae is strain 005 (= ATCC $33431=$ CDC $3278-77=$ CIP 80.34) Cedecea lapagei sp. nov. (five strains) did not ferment sucrose and D-xylose and was negative in the ornithine decarboxylase and ascorbate tests. This species grew on glucose as the role source of carbon and energy with no growth factor requirement. The type strain of $C$. lapagei is strain 004 (= ATCC $33432=$ CDC 0485-76 = CIP 80.35). Within species, deoxyribonucleic acid relatedness was 80 to $100 \%$ at $60^{\circ} \mathrm{C}$ (S1 nuclease method), and C. davisae and C. lapagei were much more closely related to each other (32 to $52 \%$ ) than to members of any other group within the family Enterobacteriaceae (1 to $21 \%$ ).
\end{abstract}

Despite the progress made in bacterial taxonomy in the last 20 years, reference laboratories frequently encounter unidentified strains. These strains are often kept in a collection which can be analyzed to detect possible groups of similar unidentified bacteria. In 1977, workers at the Centers for Disease Control gave the vernacular name "Enteric Group 15" to a group of 17 unidentified Enterobacteriaceae strains which were lipase (corn oil) positive. In 1980, we proposed a new genus, Cedecea, containing two species $(\mathrm{Ce}$ decea davisae and Cedecea lapagei) and three unspecified strains (Cedecea sp.) (J. J. Farmer, III, P. A. D. Grimont, F. Grimont, and M. A. Asbury, Abst. Annu. Meet. Am. Soc. Microbiol. 1980, C123, p. 295). However, that proposal did not constitute effective and valid publication of the scientific names.

In this paper we propose the names Cedecea gen. nov., Cedecea davisae sp. nov., and Cedecea lapagei sp. nov. for these organisms on the basis of their deoxyribonucleic acid (DNA)DNA hybridization and phenotypic characteristics. Cedecea is an arbitrarily constructed name derived from the abbreviation CDC (Centers for Disease Control).

\section{MATERIALS AND METHODS}

Bacterial strains. The Cedecea strains used in this study are listed in Table 1 . The origins of the nonCedecea reference strains used in the DNA relatedness study have been reported previously $(3,4,11)$.

Methods. A suspension of strain 005 in distilled water (about $0.02 \mathrm{ml}$ ) was deposited on a carboncoated specimen grid, negatively stained with $2 \%$ (wt/ vol) phosphotungstic acid, and examined with a Siemens Elmiskop electron microscope.

Growth factor requirements were determined by the method of Clowes and Hayes (5). Growth on various compounds as carbon and energy sources was determined by multiple inoculation (9) onto M70 minimal medium (14) supplemented with $0.01 \mu \mathrm{g}$ of thiamine per $\mathrm{ml}, 100 \mu \mathrm{g}$ of cysteine per $\mathrm{ml}, 0.5 \mu \mathrm{g}$ of para- 
TABLE 1. Origins of the Cedecea strains studied

\begin{tabular}{|c|c|c|c|c|}
\hline \multirow{2}{*}{ Species } & \multicolumn{2}{|c|}{ Strain designations } & \multicolumn{2}{|c|}{ Origin $^{a}$} \\
\hline & This paper & $\begin{array}{l}\text { Centers for Disease } \\
\text { Control }\end{array}$ & Source & Location \\
\hline \multirow[t]{9}{*}{ C. davisae } & 005 & CDC $3278-77$ & Stool & New Jersey \\
\hline & 006 & CDC $0512-78$ & Eye & New York \\
\hline & 008 & CDC 2205-78 & Sputum & United States \\
\hline & 010 & CDC $1395-75$ & Gall bladder & Alabama \\
\hline & 015 & CDC 2295-78 & Sputum & United States \\
\hline & 016 & CDC 2296-78 & Wound & United States \\
\hline & 018 & CDC 2932-78 & Urine & United States \\
\hline & 019 & CDC 1868-79 & Sputum & New York \\
\hline & 020 & CDC $1790-78$ & Wound & California \\
\hline \multirow[t]{5}{*}{ C. lapagei } & 004 & CDC 0485-76 & Throat & Canada \\
\hline & 003 & CDC 0818-75 & Sputum & Kentucky \\
\hline & 007 & CDC $0817-78$ & Sputum & New York \\
\hline & 009 & CDC 1554-75 & Sputum & Georgia \\
\hline & 017 & CDC 2488-78 & Sputum & Virginia \\
\hline \multirow[t]{3}{*}{ Cedecea sp. } & 001 & CDC 4853-73 & Sputum & New Jersey \\
\hline & 002 & CDC 0621-75 & Foot wound & California \\
\hline & 012 & CDC $3699-73$ & Toe & Canada \\
\hline
\end{tabular}

${ }^{a}$ All strains were from human clinical specimens.

aminobenzoic acid per $\mathrm{ml}$, and 0.1 to $0.2 \%$ carbon source. We used previously described procedures (9) for the following tests: Voges-Proskauer test (Richard modification), hydrolysis of gelatin (plate method), anaerobic growth in the presence of potassium chlorate, reduction of tetrathionate in peptone water, hydrolysis of tributyrin, Tween 40 , Tween 60 , Tween 80 , DNA, chitin, and starch, $o$-nitrophenyl- $\beta$-D-galactopyranoside test, $\beta$-xylosidase test with para-nitrophenyl- $\beta$-xyloside (Sigma Chemical Co.), pigment and odor production, growth with $0,2,4,6$, and $8 \% \mathrm{NaCl}$, and growth at $5,15,20,37,40$, and $42^{\circ} \mathrm{C}$. The ascorbate test was performed with ascorbate medium (Enteric fermentation base [Difco] $18 \mathrm{~g}$; bromothymol blue, $0.04 \mathrm{~g}$; sodium L-ascorbate, $10 \mathrm{~g}$; distilled water to 1,000 $\mathrm{ml}$; $\mathrm{pH} 7.5$ ) This medium was dispensed in 10-ml quantities into tubes ( 16 by $100 \mathrm{~mm}$ ) and autoclaved for $10 \mathrm{~min}$ at $121^{\circ} \mathrm{C} ; 4 \mathrm{ml}$ of mineral oil was then added, and the medium was stored at $4^{\circ} \mathrm{C}$. Tubes were discarded if the $\mathrm{pH}$ fell below 7.0. All other biochemical tests were performed as described by Edwards and Ewing (7). In addition, the Voges-Proskauer test was performed at the Centers for Disease Control by adding $0.5 \mathrm{ml}$ of API reagent $1(40 \%$ [vol/vol] $\mathrm{KOH}$ solution) and $0.5 \mathrm{ml}$ of API reagent $2(6 \%$ alphanaphthol in absolute ethanol) to $1 \mathrm{ml}$ of a 48-h culture in MR-VP broth (Difco). This method (listed in Table 5 as Voges-Proskauer-special) was a more sensitive method for detecting the acetoin pathway in Cedecea.

Susceptibilities to antimicrobial agents were determined by disk diffusion on Mueller-Hinton agar (Institut Pasteur Production), as recommended by an international study group (8). Susceptibility to the vibriostatic compound $0 / 129$ was determined on Mueller-Hinton agar with disks impregnated with $0.5 \mathrm{mg}$ of 2,4-diamino-6,7-diisopropylpteridine phosphate (synonym, compound 0/129; Institut Pasteur Production) per disk.

We used previously described procedures to label DNA with $\left[{ }^{3} \mathrm{H}\right]$ thymidine (10) to extract and purify radioactive DNAs (1), to extract and purify unlabeled DNAs, and to shear both labeled and unlabeled DNAs (2). Sheared DNAs were dialyzed overnight against $0.042 \mathrm{M} \mathrm{NaCl}$ and then stored at $4^{\circ} \mathrm{C}$ over a layer of chloroform

In the hybridization experiments, we used the $\mathrm{S} 1$ nuclease method (6), slightly modified (10). S1 nuclease was prepared by the method of Sutton (13). The DNA duplexes remaining after $\mathrm{S} 1$ nuclease treatment for $40 \mathrm{~min}$ at $60^{\circ} \mathrm{C}$ were precipitated by adding $0.25 \mathrm{ml}$ of ice-cold $25 \%$ (wt/vol) trichloroacetic acid and then collected on membrane filters (Sartorius, Göttingen, Germany). The filters were washed with three 5-ml volumes of ice-cold 5\% trichloroacetic acid, dried, and put into vials containing $10 \mathrm{ml}$ of scintillant (4 g of Koch-Light "Butyl PBD" per liter of toluene), and the radioactivity was measured with an Intertechnique model SL 4000 liquid scintillation spectrometer. The degree of polynucleotide sequence homology was calculated by determining the ratio between the average counts in the nuclease-treated samples and the average counts in the untreated samples. Results were normalized to the untreated samples and to the homologous reaction, after the percentage of S1-resistant material in the control tube (containing only denatured radioactive DNA) was subtracted. The temperature at which $50 \%$ of the reassociated DNA became hydrolyzable by $\mathrm{S} 1$ nuclease was determined by the method of Crosa et al. (6). The percent divergence $\left(\Delta T_{m}\right)(3)$ was calculated from the difference in such temperatures between the heterologous DNA reaction and the homologous DNA reaction.

The melting temperatures of $50-\mu \mathrm{g} / \mathrm{ml}$ DNA solutions in $0.1 \times \mathrm{SSC}$ buffer $(1 \times \mathrm{SSC}$ is $0.15 \mathrm{M} \mathrm{NaCl}$ plus $0.015 \mathrm{M}$ trisodium citrate) were measured by $\mathrm{M}$. Popoff, using a Gilford spectrophotometer. The guanineplus-cytosine contents of DNAs were determined from melting temperatures by the equation of Owen et al. (12). 


\section{RESULTS}

Phenotypic characterization. Figure 1 shows an electron micrograph of a representative strain of $C$. davisae (strain 005). Cells from semisolid nutrient agar were 0.6 to 0.7 by 1.3 to $1.9 \mu \mathrm{m}$ and peritrichous, with five to nine flagella.

All C. lapagei and Cedecea sp. strains could grow on glucose as the sole source of carbon and energy. However, C. lapagei 009 required cysteine to produce normal-sized colonies. All $C$. davisae strains required thiamine for growth. $C$. davisae 010 required para-aminobenzoic acid in addition to thiamine.

The characteristics of Cedecea strains that were neither 100 nor $0 \%$ positive are shown in Table 2. The characteristics which did not vary in the collection of 17 strains tested are described.

All 17 Cedecea strains were gram-negative, peritrichous (when motile), nonsporeforming, straight rods. They grew on nutrient agar at $37^{\circ} \mathrm{C}$, producing convex colonies about $1.5 \mathrm{~mm}$ in diameter. They were facultatively anaerobic. All 17 strains grew at $15,20,37^{\circ} \mathrm{C}$ at $\mathrm{pH} 7$ and 9 in tryptic soy broth and in peptone water containing 0,2 , and $4 \% \mathrm{NaCl}$. All strains produced catalase, reduced nitrates to nitrites, blackened esculin iron agar, and produced acid from $\mathrm{D}$-arabitol, cellobiose, maltose, D-mannitol, D-mannose, salicin, and trehalose.

All Cedecea strains utilized the following substrates as sole carbon and energy sources: $N$ acetylglucosamine, D-arabitol, D-cellobiose, 2ketogluconate, citrate, $\mathrm{D}$-fructose, fumarate, Dgalactose, D-galacturonate, $\beta$-gentiobiose, $D$-gluconate, D-glucosamine, D-glucose, D-glucuronate, DL-glycerate, glycerol, DL-lactate, L-malate, D-mannitol, D-mannose, pyruvate, D-ribose, salicin, and trehalose.

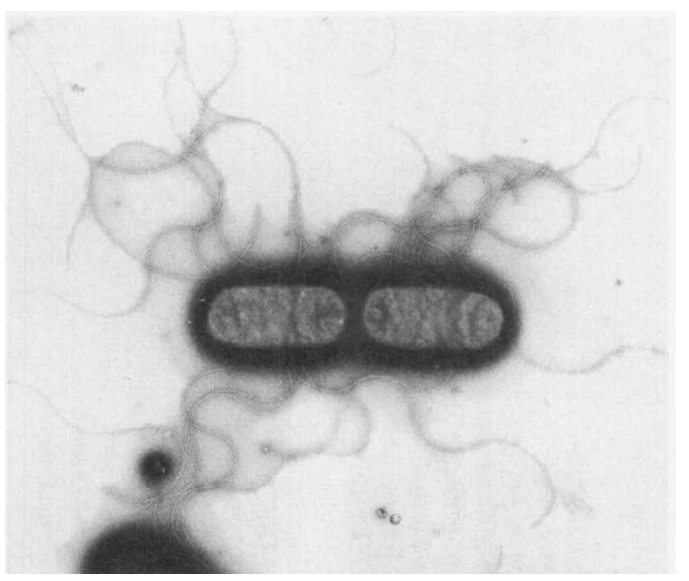

Fig. 1. Electron micrograph of C. davisae 005. Cell siz?, 1.5 by $0.7 \mu \mathrm{m}$.
None of the 17 Cedecea strains produced pigments, oxidase, indole from peptone water, $\mathrm{H}_{2} \mathrm{~S}$ from triple sugar iron agar, urease, phenylalanine deaminase, lysine decarboxylase, gelatinase (tube and plate method), deoxyribonuclease, chitinase, polygalacturonase, or amylase. There was no anaerobic growth in the presence of chlorate, and these strains did not produce acid from glucose in the presence of iodoacetate or acid in peptone water containing adonitol, $\mathbf{L}$ arabinose, dulcitol, erythritol, myo-inositol, mucate, or L-rhamnose. The tartrate test (Jordan) was negative.

No Cedecea strain could use any of the following substrates as a sole carbon and energy source: acetamide, aconitate, adipate, adonitol, $\beta$-alanine, DL-3-aminobutyrate, L-arabinose, Lascorbate, azelate, benzoate, benzylamine, betaine, 2,3-butanediol, butanol, butylamine, butyrate, DL-carnitine, L-cysteine, L-citrulline, dulcitol, $m$-erythritol, ethanol, D-fucose, L-fucose, glutarate, glycine, glycolate, heptanoate, histamine, 2-hydroxybenzoate, 3 -hydroxybenzoate, 4hydroxybenzoate, isobutanol, isobutyrate, L-isoleucine, isopropanol, isovalerate, DL-kynurenine, lactose, L-leucine, L-lysine, D-malate, maleate, D-mandelate, L-mandelate, methanol, L-methionine, nicotinate, L-norleucine, norvaline, oxalate, pelargonate, L-phenylalanine, pimelate, propanol, propionate, quinate, raffinose, L-rhamnose, sarcosine, L-sorbose, suberate, $D$-tartrate, L-tartrate, L-threonine, trigonelline, tryptamine, D-tryptophane, L-tryptophane, L-tyrosine, $n$-valerate, L-valine, and $\mathrm{D}$-xylitol. All strains were susceptible to carbenicillin, sulfonamide, trimethoprim, streptomycin, kanamycin, tobramycin, gentamicin, amikacin, chloramphenicol, tetracycline, minocycline, nalidixic acid, and furantoin, and all strains were resistant to ampicillin, cephalothin, colistin, and polymyxin (except C. davisae strain 010, which was susceptible to colistin and polymyxin); Cedecea strains 003, 004, 007, 009, 017, 006, 008, and 002 showed a double zone of inhibition around polymyxin and colistin disks.

Of the 17 strains tested, 15 were resistant to the vibriostatic compound $0 / 129$; strains 016 and 002 showed intermediate susceptibility (inhibition zone, $15 \mathrm{~mm}$ ).

DNA-DNA hybridization. The DNA relatedness data suggested that Cedecea is a new genus in the family Enterobacteriaceae and that it has at least five species. The DNA-DNA hybridization results with labeled reference DNA from C. lapagei 004 and C. davisae 005 are shown in Table 3. The S1 nuclease-resistant cores (in the incubated control tubes containing only labeled DNA) were calculated to be $4.8 \pm$ $1.5 \%$ (mean \pm standard deviation) for C. lapagei 


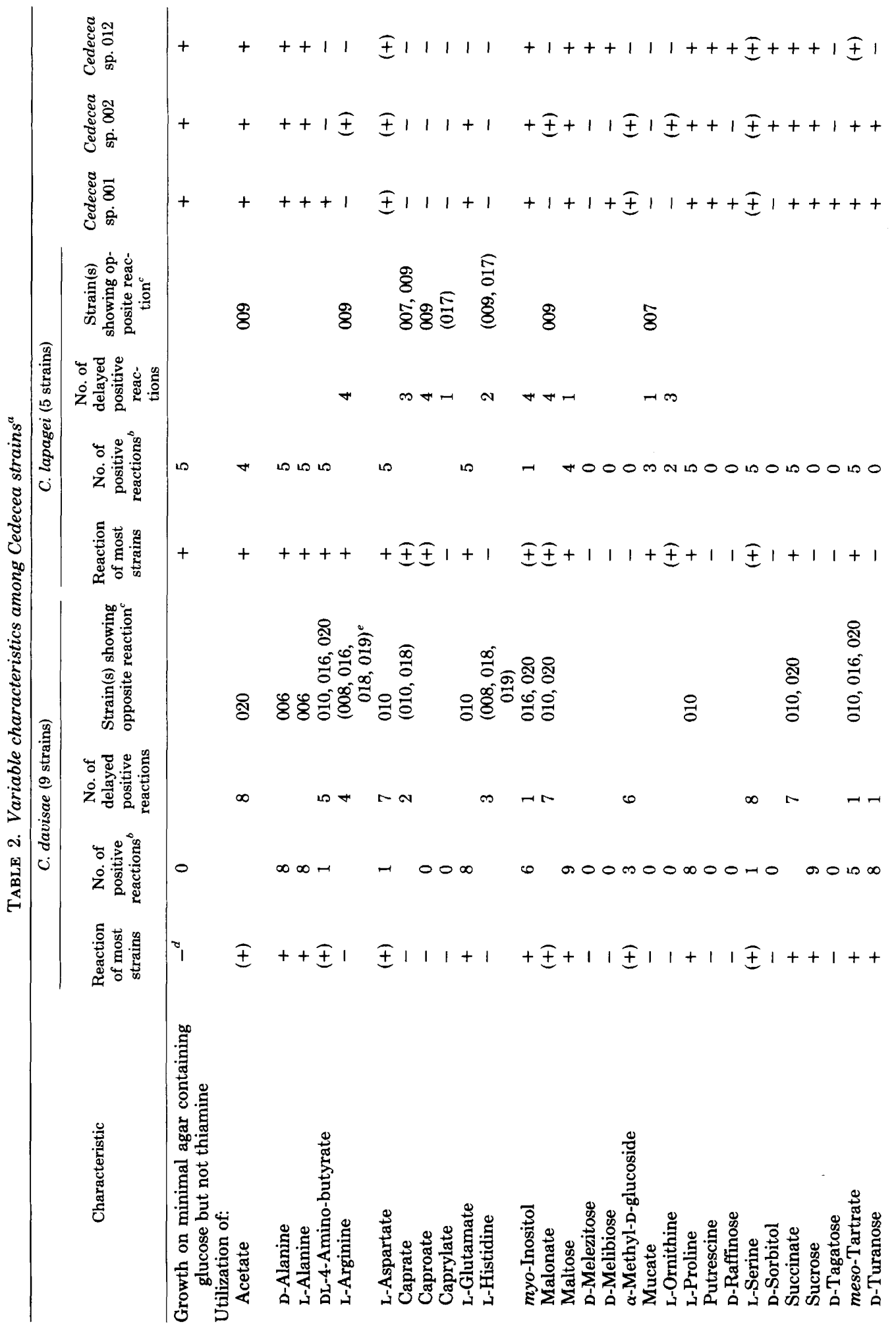


VoL. 31, 1981

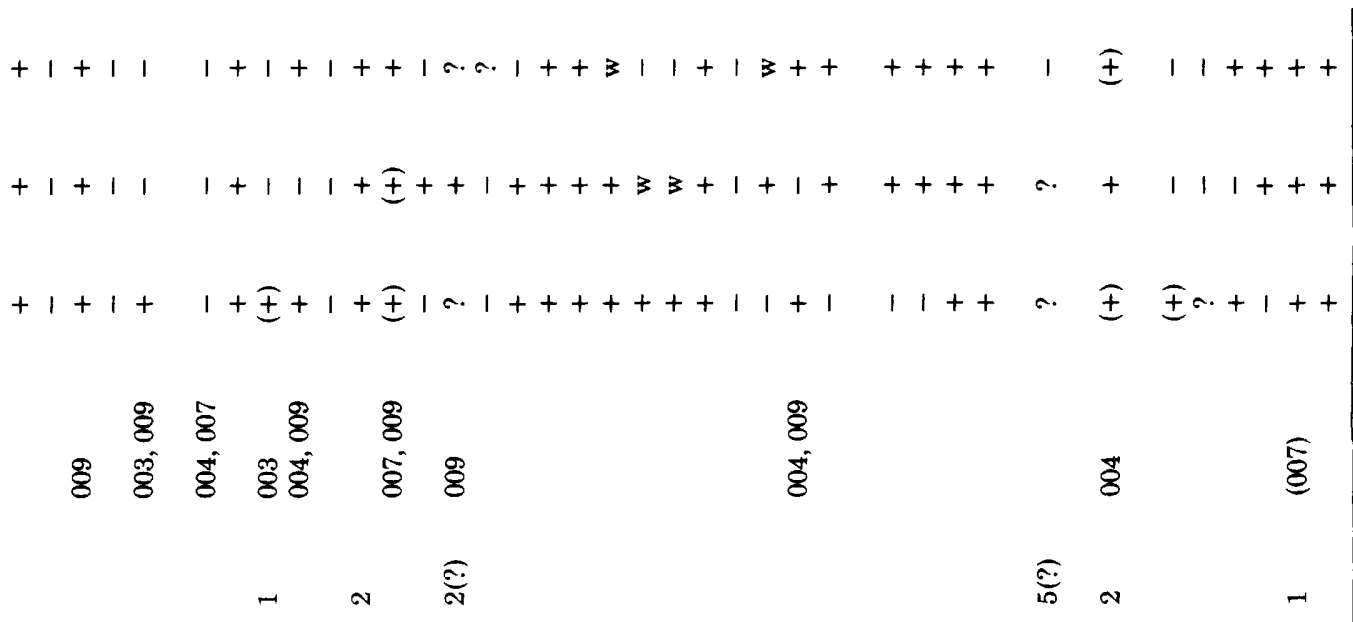

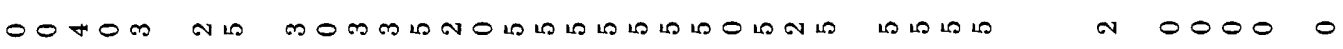

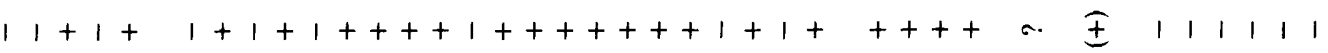

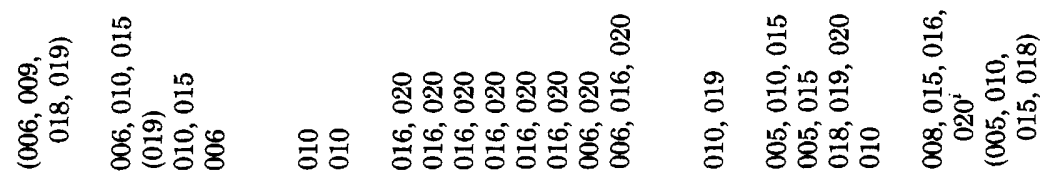

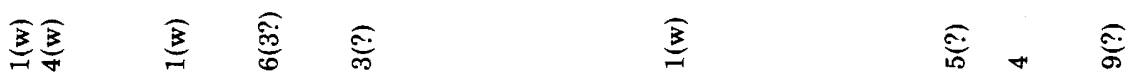

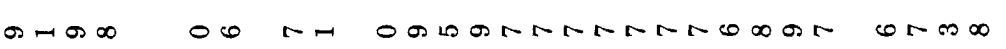
$\circ \quad 0000$

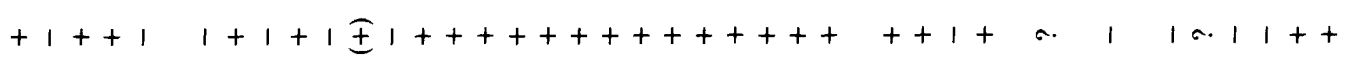

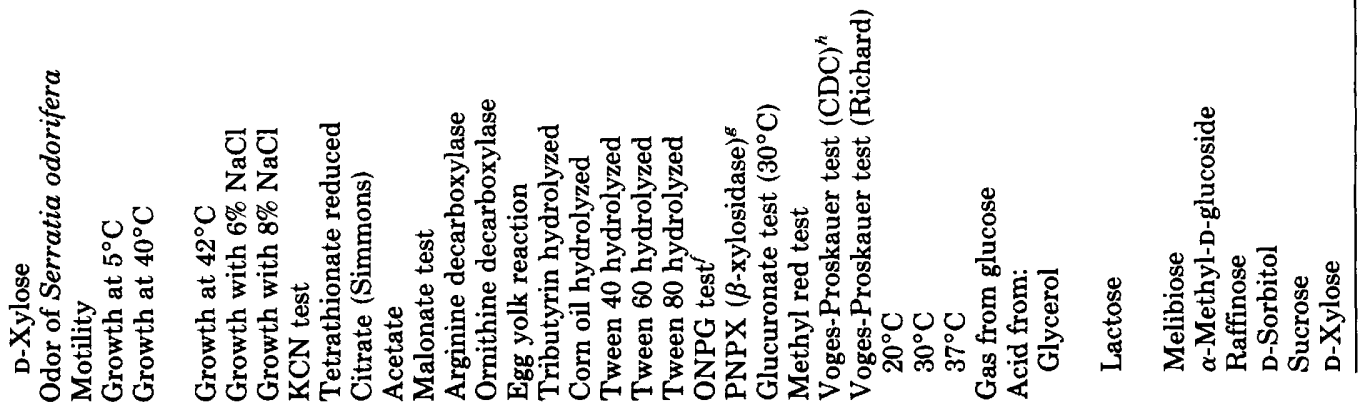




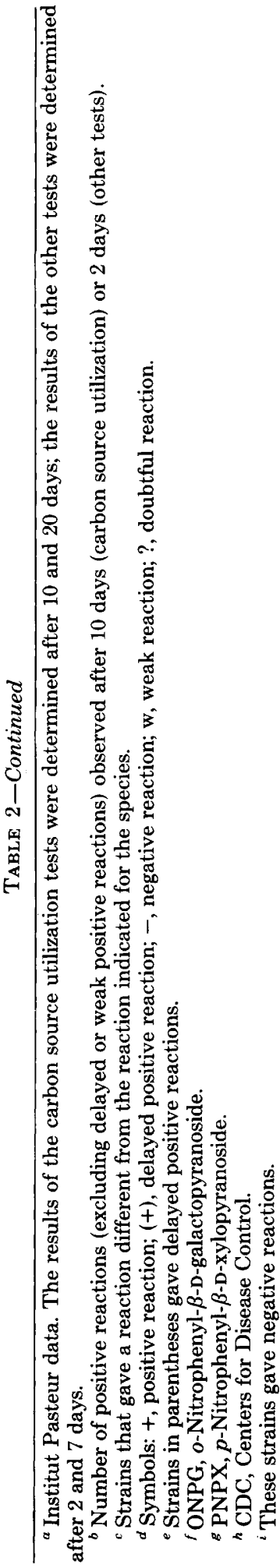

004 and $3.8 \pm 0.7 \%$ for C. davisae 005 . At $60^{\circ} \mathrm{C}$ C. lapagei strains were $88 \pm 8$ and $45 \pm 4 \%$ related to strains 004 and 005 , respectively, and C. davisae strains were $36 \pm 4$ and $92 \pm 10 \%$ related to strains 004 and 005 , respectively. Strains 001,002 , and 012 were 36 to $51 \%$ related to C. lapagei 004 and C. davisae 005 at $60^{\circ} \mathrm{C}$. The relatedness values for all other species of Enterobacteriaceae and C. lapagei 004 and $C$. davisae 005 did not exceed $23 \%$ at $60^{\circ} \mathrm{C}$.

At $75^{\circ} \mathrm{C}, C$. davisae strains were $24 \pm 5 \%$ related to strain 004 and $84 \pm 17 \%$ related to strain 005 , and C. lapagei strains were $88 \pm 11 \%$ related to strain 004 and $24 \pm 9 \%$ related to strain 005.

The $\Delta T_{m}$ values between $C$. lapagei strains and strain 004 were less than $3.3 \%$, and the $\Delta T_{m}$ values between $C$. lapagei strains and strain 005 were 9.5 to $13.3 \%$. The $\Delta T_{m}$ values between $C$. davisae strains and strain 005 were less than 4.2\%; the $\Delta T_{m}$ values between $C$. davisae strains and strain 004 were 9.7 to $12.7 \%$.

Table 4 shows the results of the DNA relatedness studies obtained with labeled reference DNAs from Cedecea sp. 001 and Cedecea sp. 012 . The S1 nuclease-resistant core was $5.2 \pm$ $0.8 \%$ for strain 001 and $5.6 \pm 0.3 \%$ for strain 012 . No relative binding ratio exceeded $56 \%$ at $60^{\circ} \mathrm{C}$.

DNA base composition. The guanine-pluscytosine contents of the DNAs of the C. davisae strains were 49 to $50 \mathrm{~mol} \%$ (strain 005, $48.8 \pm 0.8$ $\mathrm{mol} \%$; strain $018,49.6 \pm 0.4 \mathrm{~mol} \%$ ), and those of the C. lapagei strains were 48 to $52 \mathrm{~mol} \%$ (strain $004,48.1 \pm 0.9 \mathrm{~mol} \%$; strain $017,51.9 \pm 0.9$ mol\%). The DNA of Escherichia coli K-12 was tested simultaneously and contained $51.2 \pm 0.1$ mol\% guanine plus cytosine.

\section{DISCUSSION}

The DNA relatedness experiments showed that there were five DNA hybridization groups in Cedecea (represented by strains 004, 005, 001, 002 , and 012 ), two of which contained more than one strain (C. davisae and C. lapagei). We found that these hybridization groups are more closely related to each other than to any known genus in the family Enterobacteriaceae.

Phenotypically, the 17 strains which we studied do not belong in the genera Escherichia, Shigella, Salmonella, Citrobacter, Proteus, and Providencia because they are positive for the Voges-Proskauer test, the $o$-nitrophenyl- $\beta$-D-galactopyranoside test, mannitol, esculin, and lipase and negative for urease, phenylalanine deaminase, $\mathrm{H}_{2} \mathrm{~S}$, indole, and lysine decarboxylase. They do not belong in the genera Klebsiella, Enterobacter, Erwinia (including Pectobacter- 
TABLE 3. Reassociation of DNAs from C. lapagei 004 and C. davisae $005^{a}$

\begin{tabular}{|c|c|c|c|c|c|c|}
\hline \multirow{3}{*}{ Source of unlabeled DNA } & \multicolumn{3}{|c|}{ C. lapagei 004} & \multicolumn{3}{|c|}{ C. davisae 005} \\
\hline & \multicolumn{2}{|c|}{ \% Relative binding at: } & \multirow{2}{*}{$\begin{array}{c}\Delta T_{m} \\
\text { at } 60^{\circ} \mathrm{C}\end{array}$} & \multicolumn{2}{|c|}{ \% Relative binding at: } & \multirow{2}{*}{$\begin{array}{c}\Delta T_{m} \\
\text { at } 60^{\circ} \mathrm{C}\end{array}$} \\
\hline & $60^{\circ} \mathrm{C}$ & $75^{\circ} \mathrm{C}$ & & $60^{\circ} \mathrm{C}$ & $75^{\circ} \mathrm{C}$ & \\
\hline C. lapagei 004 & 100 & 100 & 0 & 46 & 26 & 10.5 \\
\hline C. lapagei 003 & 94 & 82 & 1.3 & 52 & 22 & 11.6 \\
\hline C. lapagei 007 & 84 & 92 & 0.8 & 40 & 19 & 11.5 \\
\hline C. lapagei 009 & 80 & 77 & 3.3 & 45 & 14 & 13.3 \\
\hline C. lapagei 017 & 96 & 101 & 0.6 & 43 & 37 & 9.5 \\
\hline C. davisae 005 & 34 & 24 & 10.2 & 100 & 100 & 0 \\
\hline C. davisae 006 & 36 & 24 & 10.3 & 81 & 97 & 2.4 \\
\hline C. davisae 008 & 38 & 27 & 12.7 & 96 & 105 & 2.1 \\
\hline C. davisae 010 & 32 & 22 & 9.7 & 80 & 65 & 3.0 \\
\hline C. davisae 015 & 36 & 20 & 12.3 & 95 & 67 & 3.9 \\
\hline C. davisae 016 & 32 & 16 & 10.3 & 95 & 75 & 4.2 \\
\hline C. davisae 018 & 45 & 32 & 11.0 & 106 & 98 & 1.9 \\
\hline Cedecae sp. 001 & 48 & 50 & & 51 & 29 & \\
\hline Cedecae sp. 002 & 50 & 35 & 8.8 & 50 & 27 & 12.5 \\
\hline Cedecae sp. 012 & 43 & 37 & & 36 & 25 & \\
\hline Citrobacter diversus $1066-71$ & 16 & & & 18 & & \\
\hline Citrobacter freundii $460-61$ & 12 & & & 17 & & \\
\hline Edwardsiella tarda 10396 & 7 & & & 12 & & \\
\hline Enterobacter aerogenes A1 & 14 & & & 18 & & \\
\hline Enterobacter agglomerans E20 & 9 & & & 13 & & \\
\hline Enterobacter agglomerans 3123-70 & 10 & & & 5 & & \\
\hline Enterobacter agglomerans 1429-71 & 12 & & & 11 & & \\
\hline Enterobacter agglomerans 1417-71 & 9 & & & 7 & & \\
\hline Enterobacter agglomerans 3482-71 & 11 & & & 14 & & \\
\hline Enterobacter agglomerans 6070-69 & 8 & & & 10 & & \\
\hline Enterobacter agglomerans 6003-71 & 14 & & & 13 & & \\
\hline Enterobacter agglomerans 5422-69 & 9 & & & 7 & & \\
\hline Enterobacter agglomerans 4388-71 & 23 & & & 17 & & \\
\hline Enterobacter agglomerans $1600-71$ & 19 & 10 & & 21 & 14 & \\
\hline Enterobacter agglomerans 5378-71 & 14 & & & 13 & & \\
\hline Enterobacter agglomerans 219-71 & 14 & & & 19 & & \\
\hline Enterobacter agglomerans 1645-71 & 6 & & & 4 & & \\
\hline Enterobacter cloacae $\mathrm{C} 1$ & 11 & & & 15 & & \\
\hline Enterobacter gergoviae $2-78$ & 18 & 2 & & 18 & 4 & \\
\hline Enterobacter sakazakii 4562-70 & 14 & 9 & & 17 & 11 & \\
\hline Enterobacter sp. $2898-73$ & 17 & & & 18 & & \\
\hline Erwinia amylovora EA 178 & 7 & & & 10 & & \\
\hline Erwinia carotovora 495 & 10 & & & 11 & & \\
\hline Erwinia carnegieana EC 186 & 5 & & & 4 & & \\
\hline Erwinia chrysanthemi SR 32 & 7 & & & 8 & & \\
\hline Erwinia cypripedi EC 155 & 9 & & & 12 & & \\
\hline Erwinia mallotivora 2851 & 5 & & & 2 & & \\
\hline Erwinia nigrifluens EN 104 & 7 & & & 6 & & \\
\hline Erwinia nimipressuralis E62 & 14 & & & 16 & & \\
\hline Erwinia quercina EQ 102 & 7 & & & 13 & & \\
\hline Erwinia rhapontici ER 106 & 8 & & & 14 & & \\
\hline Erwinia rubrifaciens ER 105 & 5 & & & 6 & & \\
\hline Erwinia salicis ES 102 & 7 & & & 6 & & \\
\hline Escherichia blattae 11-78 & 11 & & & 15 & & \\
\hline Escherichia coli K-12 & 10 & & & 14 & & \\
\hline Hafnia alvei $5632-72$ & 8 & & & 6 & & \\
\hline Hafnia alvei $4510-75$ & 7 & & & 8 & & \\
\hline Hafnia alvei $329-73$ & 17 & 8 & & 20 & 9 & \\
\hline Klebseilla pneumoniae 2 & 11 & & & 15 & & \\
\hline Klebsiella oxytoca 13182 & 12 & & & 12 & & \\
\hline Klebsiella sp. 4241-72 & 12 & & & 14 & & \\
\hline Levinea amalonatica 25406 & 13 & & & 16 & & \\
\hline Morganella morganii 25830 & 6 & & & 5 & & \\
\hline
\end{tabular}


TABLE 3-Continued

\begin{tabular}{|c|c|c|c|c|c|c|}
\hline \multirow{3}{*}{ Source of unlabeled DNA } & \multicolumn{3}{|c|}{ C. lapagei 004} & \multicolumn{3}{|c|}{ C. davisae 005} \\
\hline & \multicolumn{2}{|c|}{ \% Relative binding at: } & \multirow{2}{*}{$\begin{array}{c}\Delta T_{m} \\
\text { at } 60^{\circ} \mathrm{C}\end{array}$} & \multicolumn{2}{|c|}{$\%$ Relative binding at: } & \multirow{2}{*}{$\begin{array}{c}\Delta T_{m} \\
\text { at } 60^{\circ} \mathrm{C}\end{array}$} \\
\hline & $60^{\circ} \mathrm{C}$ & $75^{\circ} \mathrm{C}$ & & $60^{\circ} \mathrm{C}$ & $75^{\circ} \mathrm{C}$ & \\
\hline Obesumbacterium proteus $4302-74$ & 11 & & & 11 & & \\
\hline Proteus mirabilis PM1 & 1 & & & 1 & & \\
\hline Proteus myxofaciens 19692 & 2 & & & 2 & & \\
\hline Providencia rettgeri 1163 & 2 & & & 1 & & \\
\hline Providencia alcalifaciens $3370-67$ & 2 & & & 2 & & \\
\hline P. alcalifaciens 26240 & 1 & & & 2 & & \\
\hline Providencia stuartii 2896-68 & 1 & & & 2 & & \\
\hline Rahnella aquatilis CUEM 77-115 & 7 & & & 6 & & \\
\hline Salmonella typhimurium LT2 & 10 & & & 15 & & \\
\hline Serratia fonticola $4556-71$ & 9 & & & 9 & & \\
\hline Serratia liquefaciens 503 & 6 & & & 10 & & \\
\hline Serratia marcescens 504 & 10 & & & 13 & & \\
\hline Serratia marinorubra (S. rubidaea) & 7 & & & 11 & & \\
\hline \multicolumn{7}{|l|}{288} \\
\hline Serratia odorifera 1073 & 8 & & & 11 & & \\
\hline Serratia plymuthica 510 & 7 & & & 10 & & \\
\hline Yersinia enterocolitica 614 & 5 & & & 6 & & \\
\hline Yersinia pseudotuberculosis P 105 & 6 & & & 4 & & \\
\hline Yersinia ruckeri $4535-69$ & 4 & & & 3 & & \\
\hline
\end{tabular}

${ }^{a}$ Institut Pasteur data.

TABLE 4. Reassociation of DNAs from Cedecea sp. 001 and Cedecea sp. 012

\begin{tabular}{|c|c|c|c|c|c|c|}
\hline \multirow{3}{*}{ Source of unlabeled DNA } & \multicolumn{3}{|c|}{ Cedecea sp. 001} & \multicolumn{3}{|c|}{ Cedecea sp. 012} \\
\hline & \multicolumn{2}{|c|}{$\%$ Relative binding at: } & \multirow{2}{*}{$\begin{array}{c}\Delta T_{m} \text { at } \\
60^{\circ} \mathrm{C}\end{array}$} & \multicolumn{2}{|c|}{ \% Relative binding at: } & \multirow{2}{*}{$\begin{array}{c}\Delta T_{m} \text { at } \\
60^{\circ} \mathrm{C}\end{array}$} \\
\hline & $60^{\circ} \mathrm{C}$ & $75^{\circ} \mathrm{C}$ & & $60^{\circ} \mathrm{C}$ & $75^{\circ} \mathrm{C}$ & \\
\hline Cedecea sp. 001 & 100 & 100 & 0 & 55 & 43 & 9.2 \\
\hline Cedecea sp. 012 & 47 & 23 & 10.9 & 100 & 100 & 0 \\
\hline Cedecea sp. 002 & 56 & 49 & 6.6 & 54 & 53 & 6.8 \\
\hline C. lapagei 003 & 47 & 20 & 10.4 & 44 & 39 & 5.9 \\
\hline C. lapagei 004 & 43 & 32 & 7.0 & 43 & 41 & 5.4 \\
\hline C. lapagei 007 & 42 & 24 & & 44 & 39 & \\
\hline C. lapagei 009 & 43 & 22 & & 41 & 36 & \\
\hline C. lapagei 017 & 50 & 40 & 8.9 & 53 & 40 & 10.1 \\
\hline C. davisae 005 & 29 & 21 & 7.9 & 29 & 22 & 9.0 \\
\hline C. davisae 006 & 36 & 25 & & 35 & 25 & \\
\hline C. davisae 008 & 39 & 24 & & 34 & 29 & \\
\hline C. davisae 010 & 29 & 24 & & 29 & 24 & \\
\hline C. davisae 015 & 36 & 19 & & 30 & 25 & \\
\hline C. davisae 016 & 29 & 16 & & 27 & 17 & \\
\hline C. davisae 018 & 39 & 19 & 7.9 & 34 & 30 & 9.0 \\
\hline Enterobacter sakazakii 4562-70 & 17 & 10 & & 12 & 7 & \\
\hline Enterobacter gergoviae $2-78$ & 11 & 5 & & 8 & 8 & \\
\hline Enterobacter agglomerans $1600-71$ & 17 & 11 & & 16 & 7 & \\
\hline Hafnia alvei $329-73$ & 15 & 9 & & 16 & 9 & \\
\hline
\end{tabular}

ium), and Serratia because they are positive for lipase and D-arabitol and negative for lysine decarboxylase, gelatinase, deoxyribonuclease, chitinase, polygalacturonase, L-rhamnose, and L-arabinose. For these reasons we propose a new genus for the 17 strains described in this study. Cedecea gen. nov. is an arbitrarily constructed name derived from the abbreviation CDC (Cen- ters for Disease Control) and is treated as a Medieval Latin feminine substantive. The two hybridization groups containing more than one strain are named as follows: Cedecea davisae sp. nov., type species of the genus Cedecea, with strain 005 (= ATCC $3343=$ CDC $3278-77=$ CIP 80.34) as the type strain; and Cedecea lapagei sp. nov., with strain 004 (= ATCC $33432=$ CDC 
0485-76 = CIP 80.35) as the type strain. The specific epithet of C. davisae is a Medieval Latin, genitive, feminine form of Davis, in honor of Betty R. Davis, American bacteriologist. The specific epithet of $C$. lapagei is a Medieval Latin, genitive, masculine form of Lapage, in honor of Stephen P. Lapage, British bacteriologist.

Description of the genus Cedecea. The

TABLE 5. Summary of the reactions of Cedecea in biochemical tests which are normally used in enteric bacteriology for identification ${ }^{\alpha}$

\begin{tabular}{|c|c|c|c|c|c|}
\hline Test & $\begin{array}{c}\text { C. davisae } \\
\text { (nine strains) }\end{array}$ & $\begin{array}{c}\text { C. lapagei } \\
\text { (five strains) }\end{array}$ & $\begin{array}{c}\text { Cedecea sp. } \\
001\end{array}$ & $\begin{array}{c}\text { Cedecea } \mathrm{sp} . \\
002\end{array}$ & $\begin{array}{c}\text { Cedecea sp. } \\
012\end{array}$ \\
\hline Indole & - & - & - & - & - \\
\hline Methyl red & + & V & + & + & + \\
\hline Voges-Proskauer-normal & - & $(+)$ & - & - & - \\
\hline Voges-Proskauer-special & $(+)$ & + & - & + & + \\
\hline Citrate & $(+)$ & + & + & + & + \\
\hline $\mathrm{H}_{2} \mathrm{~S}$ (triple sugar iron) & - & - & - & - & - \\
\hline Urea & - & - & - & - & - \\
\hline Phenylalanine & - & - & - & - & - \\
\hline Lysine (Moller) & - & - & - & - & - \\
\hline Arginine (Moller) & $(+)$ & $(+)$ & + & + & + \\
\hline Ornithine (Moller) & $(+)$ & - & - & - & + \\
\hline Motility & + & $(+)$ & + & + & + \\
\hline Gelatin $\left(22^{\circ} \mathrm{C}\right)$ & - & - & - & - & - \\
\hline $\mathrm{KCN}$ & $(+)$ & + & + & - & + \\
\hline Malonate & $(+)$ & + & - & + & - \\
\hline D-Glucose (acid) & + & + & + & + & + \\
\hline D-Glucose (gas) & $\mathrm{V}$ & + & + & + & + \\
\hline Lactose & $(-)$ & $(+)$ & - & + & - \\
\hline Sucrose & + & - & + & + & + \\
\hline D-Mannitol & + & + & + & + & + \\
\hline Dulcitol & - & - & - & - & - \\
\hline Salicin & + & + & + & + & + \\
\hline Adonitol & - & - & - & - & - \\
\hline$i$-Inositol & - & - & - & - & - \\
\hline D-Sorbitol & - & - & - & + & + \\
\hline L-Arabinose & - & - & - & - & - \\
\hline Raffinose & - & - & + & - & + \\
\hline L-Rhamnose & - & - & - & - & - \\
\hline Maltose & + & $(+)$ & + & + & + \\
\hline D-Xylose & + & - & + & + & + \\
\hline Trehalose & + & + & + & + & + \\
\hline Cellobiose & + & + & + & + & + \\
\hline$\alpha$ - $\mathrm{CH}_{3}$-glucoside & $(-)$ & - & + & + & - \\
\hline Erythritol & - & - & - & - & - \\
\hline Esculin & V & + & + & + & + \\
\hline Melibiose & - & - & + & - & + \\
\hline D-Arabitol & + & + & + & + & + \\
\hline Glycerol & - & - & - & - & - \\
\hline Mucate & - & - & - & - & - \\
\hline Jordan tartrate & - & - & - & - & - \\
\hline Acetate & - & $\mathrm{V}$ & + & - & - \\
\hline Lipase (corn oil) & $(+)$ & + & + & + & - \\
\hline Deoxyribonuclease $\left(25^{\circ} \mathrm{C}\right)$ & - & - & - & - & - \\
\hline $\mathrm{NO}_{3}^{-} \rightarrow \mathrm{NO}_{2}^{-}$ & + & + & + & + & + \\
\hline Oxidase & - & - & - & - & - \\
\hline $\mathrm{ONPG}^{c}$ & + & + & + & + & + \\
\hline Pigment & - & - & - & - & - \\
\hline D-Mannose & + & + & + & + & + \\
\hline Tyrosine clearing & - & - & - & - & - \\
\hline
\end{tabular}

${ }^{a}$ Centers for Disease Control data $\left(48 \mathrm{~h}, 36^{\circ} \mathrm{C}\right)$.

${ }^{b}+, 90$ to $100 \%$ positive; $(+), 75$ to $89 \%$ positive; $V, 26$ to $74 \%$ positive; $(-), 11$ to $25 \%$ positive;,- 0 to $10 \%$ positive.

${ }^{c}$ ONPG, $\alpha$-Nitrophenyl- $\beta$-D-galactopyranoside. 
genus Cedecea is composed of motile, non-encapsulated, gram-negative rods that conform to the definition of the family Enterobacteriaceae.

The Voges-Proskauer and $o$-nitrophenyl- $\beta$-Dgalactopyranoside tests are positive. Lysine is not decarboxylated, and indole, $\mathrm{H}_{2} \mathrm{~S}$, urease, and phenylalanine deaminase are not produced. Lipase is produced, but gelatinase, deoxyribonuclease, chitinase, amylase, and polygalacturonase are not. Gas is formed from the fermentation of glucose. Acid is produced from D-arabitol, Dcellobiose, maltose, D-mannitol, mannose, salicin, and trehalose but not from adonitol, Larabinose, dulcitol, or L-rhamnose. Esculin is hydrolyzed. Resistance to colistin, polymyxin, and cephalothin is common. The guanine-pluscytosine content to the DNA is about 48 to 52 mol\%. The type species is C. davisae.

C. davisae and C. lapagei can be differentiated easily by ornithine decarboxylase and ascorbate tests and by acid production from $D$ xylose and sucrose (positive for $C$. davisae), production of $\beta$-xylosidase (positive for most $C$. davisae strains), and the specific thiamine requirement for growth of $C$. davisae. Further descriptions of the Cedecea species are given above and in Table 2. Table 5 provides a summary of the biochemical characteristics which are useful in the identification of $C$. davisae and C. lapagei strains in clinical bacteriology laboratories. The clinical significance of Cedecea spp. is not yet known.

\section{ACKNOWLEDGMENTS}

We thank Michel Y. Popoff for performing the guanineplus-cytosine determinations.

The part of the work done in France was supported by grant 78.4.139 from Institut National de la Santé et de la Recherche Médicale.

\section{REPRINT REQUESTS}

Address reprint requests to: P. A. D. Grimont, Service des Entérobactéries, Institut Pasteur, F-75724 Paris Cedex 15, France.

\section{LITERATURE CITED}

1. Brenner, D. J., G. R. Fanning, K. E. Johnson, R. V. Citarella, and S. Falkow. 1969. Polynucleotide sequence relationships among members of the Enterobacteriaceae. J. Bacteriol. 98:637-650.

2. Brenner, D. J., G. R. Fanning, F. J. Skerman, and S. Falkow. 1972. Polynucleotide sequence divergence among strains of Escherichia coli and closely related organisms. J. Bacteriol. 109:953-965.

3. Brenner, D. J., J. J. Farmer III, G. R. Fanning, A. G. Steigerwalt, P. Klykken, H. G. Wathen, F. W. Hickmann, and W. H. Ewing. 1978. Deoxyribonucleic acid relatedness of Proteus and Providencia species. Int. J. Syst. Bacteriol. 28:269-282.

4. Brenner, D. J., A. G. Steigerwalt, D. P. Falcão, R. E. Weaver, and G. R. Fanning. 1976. Characterization of Yersinia enterocolitica and Yersinia pseudotuberculosis by deoxyribonucleic acid hybridization and by biochemical reactions. Int. J. Syst. Bacteriol. 26:180194.

5. Clowes, R. C., and W. Hayes. 1968. Experiments in microbial genetics. Blackwell Scientific Publications, Oxford.

6. Crosa, J. H., D. J. Brenner, and S. Falkow. 1973. Use of a single-strand-specific nuclease for analysis of bacterial and plasmid deoxyribonucleic acid homo- and heteroduplexes. J. Bacteriol. 115:904-911.

7. Edwards, P. R., and W. H. Ewing. 1972. Identification of Enterobacteriaceae, 3rd ed. Burgess Publishing Co., Minneapolis.

8. Ericsson, H. M., and J. C. Sherris. 1971. Antibiotic sensitivity testing: report of an international collaborative study. Acta Pathol. Microbiol. Scand. Suppl. 217: 64-71.

9. Grimont, P. A. D., F. Grimont, H. L. C. Dulong de Rosnay, and P. H. A. Sneath. 1977. Taxonomy of the genus Serratia. J. Gen. Microbiol. 98:39-66.

10. Grimont, P. A. D., F. Grimont, and M. P. Starr. 1978 Serratia proteamaculans (Paine and Stansfield) comb. nov., a senior subjective synonym of Serratia liquefa ciens (Grimes and Hennerty) Bascomb et al. Int. J. Syst. Bacteriol. 28:503-510.

11. Grimont, P. A. D., F. Grimont, and M. P. Starr. 1979. Serratia ficaria sp. nov., a bacterial species associated with Smyrna figs and the fig wasp Blastophaga psenes. Curr. Microbiol. 2:277-282.

12. Owen, R. J., L. R. Hill, and S. P. Lapage. 1969. Determination of DNA base compositions from melting profiles in dilute buffers. Biopolymers 7:503-516.

13. Sutton, W.D. 1971. A crude nuclease preparation suitable for use in DNA reassociation experiments. Biochim. Biophys. Acta 240:522-531.

14. Véron, M. 1975. Nutrition et taxonomie des Enterobac teriaceae et bactéries voisines. I. Méthode d'étude des auxanogrammes. Ann. Microbiol. Paris 126A:267-274. 